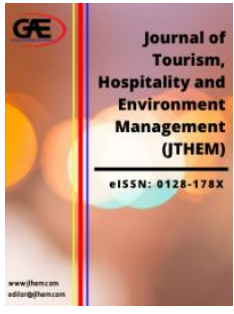

\author{
JOURNAL OF TOURISM, \\ HOSPITALITY AND \\ ENVIRONMENT MANAGEMENT \\ (JTHEM) \\ www.jthem.com
}

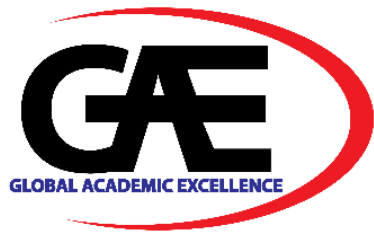

\title{
AN INVESTIGATION OF TUNKU ABDUL RAHMAN MARINE PARK, SABAH'S ATTRACTIONS AND TOURISM INFRASTRUCTURE MANAGEMENT
}

\author{
Mohamad Pirdaus Yusoh ${ }^{1}$, Noorziah Mohd Salleh ${ }^{2}$, Jabil Mapjabil ${ }^{3 *}$,Rosmiza M.Z. ${ }^{4}$ \\ 1 Center for Fundamental and Continuing Education, Universiti Malaysia Terengganu \\ Email: m.pirdaus@umt.edu.my \\ 2 Faculty of Business and Management, Universiti Teknologi MARA Kampus Sabah \\ Email: noorziah@sabah.uitm.edu.my \\ 3 Borneo Institute for Indigenous Studies (BorIIS), Universiti Malaysia Sabah \\ Email: jabil@ums.edu.my \\ 4 Geography Program, Center for Research in Development, Social and Environment, Faculty of Social Sciences and \\ Humanities, Universiti Kebangsaan Malaysia \\ Email: miza@ukm.edu.my \\ * Corresponding Author
}

\section{Article Info:}

\section{Article history:}

Received date: 23.08 .2021

Revised date: 15.09 .2021

Accepted date: 27.09 .2021

Published date: 30.09 .2021

\section{To cite this document:}

Yusoh, M. P., Salleh, N. M., Mapjabil, J., \& Rosmiza, M. Z. (2021). An Investigation of Tunku Abdul Rahman Marine Park, Sabah's Attractions and Tourism Infrastructure Management. Terengganu. Journal of Tourism, Hospitality and Environment Management, 6 (24), 87-99.

DOI: $10.35631 /$ JTHEM.624008.

\begin{abstract}
:
Tunku Abdul Rahman Marine Park (TLTAR) is a marine park established under the Establishment of Marine Parks Malaysia Order 1994 of the Department of Fisheries to conserve marine resources and develop tourism. It consists of five islands, namely Manukan Island, Mamutik Island, Sapi Island, Sulug Island, and a portion of Gaya Island. The marine park has an area of 4,929 hectares, of which two-thirds are submerged. The purpose of the study is to investigate the characteristics of tourist attractions and tourism infrastructure in TLTAR, Sabah. The study involved 249 respondents, including locals who have visited TLTAR. The majority of respondents $(71.5 \%)$ were male, $75.5 \%$ were under 30 years old, $68.7 \%$ were single, and over $50 \%$ had secondary education. The results of this study revealed that there were three main attractions that attracted visitors to TLTAR, which included the beauty of the beach and water surrounding it, the peaceful island environment, and recreational activities such as snorkelling, scuba diving, and picnicking. The island environment, particularly its beach, and the safety of the island, particularly perceived threats from certain parties and crimes, are also a few factors that need to be addressed in order for visitors to continue visiting TLTAR. In terms of the level of tourism infrastructures, the findings indicate that the recreational facilities, boat services, and jetty provided are better than
\end{abstract}


This work is licensed under CC BY 4.0

(a) those offered by others in Malaysia. The findings of the study are important for policymakers and marine park development planners in ensuring more sustainable tourism management and creating enjoyable and satisfaction for all visitors.

Keywords:

Attractions, Facilities, Visitors, Tourism Infrastructure, Tunku Abdul Rahman Marine Park (TLTAR), Tourism Infrastructure Management

\section{Introduction}

Islands have their own unique characteristics that make them attractive as tourist destinations. It is the image of 'sun, sand and sea' (3S) that is a universal attraction that encourages tourists to come and visit. Mendoza-González et al. (2018) report that tourism is becoming a mass phenomenon every year, with millions of visitors and tourists choosing the beach as their destination for relaxation and recreation and is becoming increasingly popular. Island tourism is popular in five regions of the world that comprise archipelagos, including the Caribbean Sea, Mediterranean Gulf, Pacific Ocean, Indian Ocean, and Southeast Asian region (Pearce, 1987). Aside from the $3 \mathrm{~S}$ concept, there are also islands that have managed to establish their own unique image and appeal to international tourists. Bahamas Island is known for its reputation as a gambling center, Fiji Island as a duty-free shopping paradise, Dominica Republic with its historical monuments, Bali Island with its unique community culture, and Easter Island which is a popular archaeological site. Each island tourist destination has its own unique characteristics and special features that contribute to its success as a tourist destination. The island tourism industry is a product of the commercial sector that enables tourists to enjoy both natural and manmade resources in one geographic location (Jun Yang et al. 2016).

Generally, tourism development affects both the physical environment and the human environment of islands. The majority of islands in the world share a number of characteristics, such as small size, a small population, traditional socio-economic structures, underdevelopment, remote locations, limited basic resources, and inadequate infrastructure facilities (Wilkinson, 1989; Jabil et al., 2014). Tourism is an ideal sector for driving growth on an island due to its attributes of 'smallness' and limited resources. Tourism is more popular on tropical islands such as those in the Caribbean and the Pacific Ocean. Some Caribbean islands, including Antigua Island, Puerto Rico, and the United States Virgin Islands, have been popular tourist destinations since the 1950s.

The tourism industry plays an important role in the economic development of the island community, in addition to the fishing industry, which has been an important source of income for generations. The characteristics of an island's tourist attraction should be unique and attractive, and the level of accommodation must be suitable and adequate in order to enhance the competitiveness of the island's tourism industry. Thus, the purpose of this article is to investigate the characteristics of attractions and the level of tourism facilities in Tunku Abdul Rahman Marine Park, Sabah. 


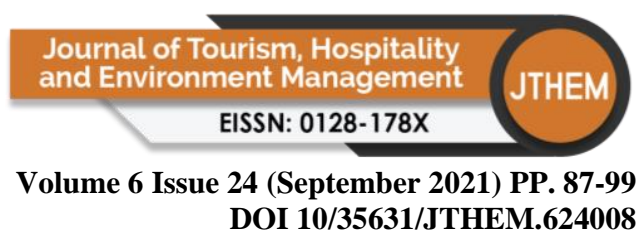

\section{Malaysian Island Tourism}

Island is one of the major tourist destinations in Malaysia, apart from its unique culture, food, festivals and shopping malls (Hofmann, 1979). History of the island in Malaysia can be traced back to the Dutch colonial era in 16th century Malaya. The Langkawi archipelago, comprised of 99 islands, was used as a resting place in 1642 for soldiers injured or ill while serving in the waters of Southeast Asia (Kadir, 1993). Pulau Rawa, Pulau Pemanggil, Pulau Sibu and Pulau Tinggi comprise the archipelago located off the east coast of Johor. Each of these islands presents its own unique characteristics as a tourist destination. Pulau Tinggi, which is situated at a height of 2,000 feet above sea level, has been a center of the spice trade since the 13th century. Tajaluddin (1994) notes that the island has been a stopover destination for spice traders from the east and west for the past 600 years. In the 1930s, Pangkor Island began to be visited by tourists including Europeans, especially the British who had served in Malaya as colonial officials, mine operators, farm operators, and engineers. They have constructed three bungalows along Pasir Bogak, located on the island of Pangkor.

Malaysia has had an island tourism industry since time immemorial, but more serious and planned efforts were not initiated until the late 1980s. In Malaysia, before this development, most islands, except for Penang, had a small population and relied heavily on fishing and marine products for their livelihood (Wong, 1993). In the Second Malaysia Plan (1971-1975), island tourism destinations were not included as part of the development agenda. The Third Malaysia Plan (1976 - 1980) allocated a number of funds to develop tourism along the east coast of Peninsular Malaysia with the aim of diverting tourists away from Kuala Lumpur and Penang (Malaysia, 1975). Langkawi Island and Tioman Island were both included in the island tourism development strategy in the Fifth Malaysia Plan (1986 - 1990) (Malaysia, 1985). In fact, Pulau Langkawi, Pulau Pangkor and Pulau Tioman also benefited from efforts undertaken as part of the Sixth Malaysia Plan (1991 - 1995) (Malaysia, 1991) to upgrade infrastructure related to tourism.

The development of island tourism in Malaysia can be divided into several areas (Wong, 1993). The areas include the north (Pulau Perhentian, Pulau Redang and Pulau Kapas while in the southern part of the island includes Pulau Tioman, Pulau Rawa, Pulau Tengah, Pulau Babi Besar, Pulau Sibu, Pulau Pemanggil and Pulau Au). and the west, east coast. The west coast of Peninsular Malaysia is divided into two archipelagos, namely Langkawi Island, Penang Island, Pangkor Island and Pulau Besar. In Sabah, there are island that have the potential for tourism development namely Pulau Gaya, Pulau Manukan, Pulau Mamutik, Pulau Sapi and Pulau Sulug (known as Tunku Abdul Rahman Marine Park) and Pulau Layang- Kites in the waters of the South China Sea, Selingan Island in the waters of the Sulu Sea and Sipadan Island, Mabul Island, Kapalai Island, Ligitan Island and Pandanan Island and several other islands in the waters of the Sulawesi Sea (Jabil et al., 2014).

As the result of the discovery and declaration of Sipadan Island in 1987 as one of the best scuba diving destinations in the world, island tourism in Malaysia is gaining increasing international popularity. Malaysia has developed a reputation as a diving destination among international tourists due to its diverse, unique marine natural treasures. They are exotic and fascinating. The waters surrounding Malaysia, especially the archipelago in the Straits of Malacca, the South China Sea, and the Sulawesi Sea, are rich in marine life. The clear and deep water of the sea is a challenge for those who enjoy maritime activities. By making an island a marine park, its Copyright (C) GLOBAL ACADEMIC EXCELLENCE (M) SDN BHD - All rights reserved 


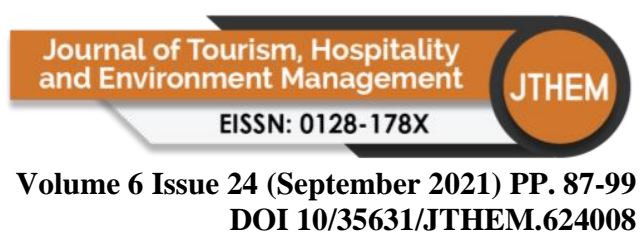

development can be controlled and preserved. There is a peaceful and enchanting atmosphere surrounding the marine reserve, which encourages many domestic and foreign tourists to visit. Norlida Hanim et al. (2017) contend that the status of a marine park demands that tourism development be carried out carefully and strategically. It is also necessary to emphasize a variety of aspects in order to ensure that the natural beauty of marine flora and fauna in Tunku Abdul Rahman Marine Park continues to be preserved and remains sustainable. Therefore, in this article, we investigate the perception of visitors from locals regarding the characteristics of attractions at Tunku Abdul Rahman Marine Park, and the level of tourist facilities that are available to visitors.

\section{Literature Highlights - Characteristics of Tourist Attractions and the Level of Tourist Facilities}

In many cases, characteristics of tourist attractions are described based on the opinions of visitors and tourists regarding the destination's ability to meet their holiday requirements. According to Formica (2002), there is research that indicates a study of the characteristics of tourist attractions is useful in understanding what motivates tourists to travel. Apart from the characteristics of tourist attractions, the level of facilities provided at the resort also affects the satisfaction of tourists. Studies have been conducted on the characteristics of tourist attractions that are considered important when evaluating a tourist destination (Mohd Anuar, 2009; Vengesayi et al., 2009; Norazimah, 2015; Velan et al., 2015; Remali \& Nor 'Azurah (2017).

Mohd Anuar (2009) carried out a study of the characteristics of beach tourism attractions using Port Dickson, Negeri Sembilan as a case study. As part of his research, he examined the factors that can attract visitors to the beach area as a tourist destination. Generally, one wonders whether it is because of the beautiful beaches, the peaceful environment, or infrastructure facilities, or maybe there are other factors that attract tourists to the area. Mohd Anuar's study found that the main reason tourists come to Port Dickson is its proximity to their home (53\%), which is within $80 \mathrm{~km}$, followed by comfortable accommodations (27\%), and beautiful beaches $(17 \%)$. As compared to generic features, $94 \%$ of respondents stated that they could reach the destination easily, $96 \%$ stated that the accommodation is affordable, and $70 \%$ agreed that the destination offered good basic facilities, quality services, and they could move around it easily (79\%), as well as providing various activities (90\%). On the subject of specific features, a majority of respondents (90\%) affirmed that Port Dickson beach is clean, quality ecosystem $(67 \%)$, charming environment (97\%), safe beach environment $(91 \%)$, beach activities that are interesting (100\%), quality sea sports (97\%), and interesting night activities (80\%).

Remali and Nor'Azurah (2017) investigated the factors of tourist attraction in Pantai Irama, Bachok, Kelantan. The results show that the main reason visitors come to this beach is because of its location close to the area where the respondents live, which is 43 percent. This proves the majority of visitors are locals. While other factors are such as complete facilities (25\%), attractive beaches (16\%) and accommodation facilities offered (14\%). From the aspect of generic features, the majority of respondents stated that the basic facilities provided are complete (98\%), easy to access here (90\%), good quality of accommodation facilities $(85 \%)$, easy to move in the surrounding area $(75 \%)$ and offer various facilities for visitor activities (70\%). This shows that Pantai Irama has interesting generic features and has a high appeal. While from the aspect of specific characteristics, most respondents think that the beach is clean 


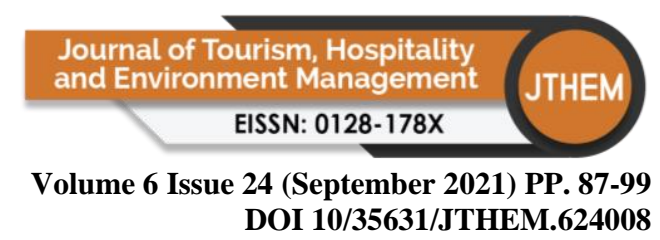

(90\%), attractive environment (97\%), safe (91\%), various beach activities (98\%), water sports activities are provided (97\%) and attractive ecosystems (67\%).

Further, Vengesayi et al. (2009) reviewed the characteristics of tourist attractions, destination support facilities, and visitors as human factors related to tourist destinations. In the study, 275 tourists visited major tourist attractions in the study area. According to the regression model developed by the study, characteristics of tourist attractions are the main determinants of tourist destinations, while aspects of facilities and destination support services as well as human factors are secondary determinants. As the result of the research, it was found that the characteristics of tourist attractions, destination support services, and human-related factors accounted for $43 \%$ of the variance in the characteristics of destination attractions studied. There are a number of positive and significant features associated with the tourist attractions of the destinations studied (man-made, historic, unique). Further, accessibility and accommodation facilities are important factors that directly influence the appeal of a destination.

Norazimah (2015) also investigated the relationship between tourist destination characteristics and visitor satisfaction, but in the context of repeat visits to Melaka. The sample consisted of 358 domestic tourists who had visited Melaka at least once, and the instrument used in the study was a questionnaire. The results showed that the aspect of historical attractions is the characteristic of the destination with the highest mean score, which is 4.37. Furthermore, there is a high correlation between tourist satisfaction with the aspects of the destination, namely recreational tourist attractions, cleanliness, and spending while in Melaka. While the characteristics of the destination, such as historical tourist attractions, variety of food, accommodation facilities, accessibility, road direction, quality of the staff, infrastructure facilities, security, food prices, and friendliness of the locals, show a moderate relationship. Moreover, there is a very low and insignificant correlation between characteristics of a destination and repeat visits to Melaka.

Velan et al. (2015) examined the satisfaction of international tourists with the facilities and activities of Mamutik Island, Kota Kinabalu. Among the main attractions and activities on the island are scuba diving, swimming, and watching marine life. There are many tourist amenities and services available, such as piers, toilets, picnic and barbeque areas, sunbathing facilities and stalls. A total of 150 respondents representing international tourists participated in this study. The results indicate that the majority of respondents were satisfied with the activities and facilities on Mamutik Island. There are some aspects however that need to be addressed by the management in order to increase the satisfaction level of visitors, including increase the number of toilets and other facilities, diversifying the activities offered and providing scuba diving facilities at an affordable price. Among the significant findings of this study is that the variety of activities and the level of quality facilities can ensure the loyalty of international tourists to continue to return to the state's tourist destinations.

In the case of sustainable development in tourism, several important issues include knowledge about the needs and challenges faced by both hosts and tourists, as outlined by Fathilah et al. (2020). Due to the fact that tourism is a global business, it is imperative to examine these two issues from a cross-cultural perspective. The present study examines cross-cultural exchanges between hosts and tourists, as well as the impact of cultural differences on the characteristics of tourist destinations. In a cross-cultural approach, the sample is grouped according to the Copyright $\odot$ GLOBAL ACADEMIC EXCELLENCE (M) SDN BHD - All rights reserved 


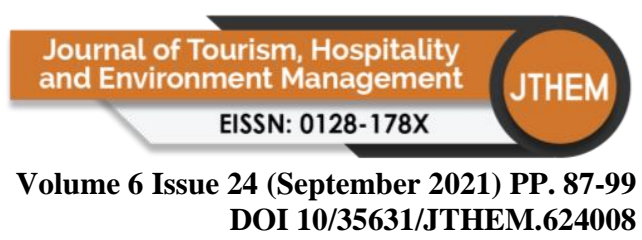

language spoken, such as Malay, Chinese, English, and non-English. A quantitative method was used in this study to evaluate three island destinations, which included two small islands, Perhentian Island and Redang Island, as well as a large island, Langkawi Island. In total, 1,285 respondents were interviewed for this study. The results of the study revealed that hosts and tourists from different cultural groups behaved differently toward the characteristics of the study destinations. This study contributes to the literature on consumer behaviour in a crosscultural context. In fact, this study also enriches knowledge regarding the characteristics of destinations and the services offered and emphasizes the importance of cultural differences in the provision of quality services for the sustainability of island tourism.

\section{The Tunku Abdul Rahman Marine Park}

Marine parks are areas of marine waters zoned at 2 nautical miles from the lowest low tide. The Park was established to preserve a variety of aquatic habitats and marine life. Tunku Abdul Rahman Marne Park (TLTAR) is one of the marine parks in Malaysia established by the Establishment of Marine Parks Malaysia Order 1994 to conserve marine resources and promote tourism. It consists of five islands: Manukan Island, Mamutik Island, Sapi Island, Sulug Island, and part of Gaya Island. The marine park covers an area of 4,929 hectares, of which two thirds are marine. The boat ride from Kota Kinabalu to TLTAR takes just 10 to 20 minutes. In addition to the marine attractions, Taman Tunku Abdul Rahman also has priceless forest treasures. Nordin et al. (2016) report that Pulau Gaya has been a forest reserve since 1923.

\section{Gaya Island}

TLTAR's largest island is Gaya Island. The island has an area of 1,465 hectares and is included in the Tunku Abdul Rahman Marine Park gazette. Therefore, the island is protected from fishing activities, illegal logging, petroleum exploration, and other sources of pollution. A boat ride to Gaya Island takes 10 minutes from Kota Kinabalu. In the part of Gaya Island known as TLTAR, scuba divers can enjoy the beauty of the seabed. There are settlements dominated by the Bajau and Suluk tribes on the part of the island overlooking Kota Kinabalu. Islanders have access to a variety of facilities including schools, clean water supply, electricity supply, and so on. Pulau Gaya's residents primarily travel by boat and fishing boat.

\section{Manukan Island}

Manukan Island is the second largest island in TLTAR at 20 hectares. It takes 20 minutes by boat to reach the island from Kota Kinabalu. Manukan Island is known for its clear water and its coral reefs. It is a popular tourist destination for snorkelling, diving, swimming and picnicking. As opposed to other islands, Manukan Island has a number of facilities, such as chalets, clubhouses, restaurants, swimming pools, game courts, scuba diving and snorkelling centres, as well as ice cream stands by the beach.

\section{Mamutik Island}

Mamutik Island is a small island with a surface area of six hectares. The island is located closest to Kota Kinabalu compared to the others. There are basic facilities such as public toilets, several chalets, dressing rooms, clean water supply, electricity supply and a place for barbecue. Mamutik Island has its own specialty with clear sea water, corals and marine life that is unique and rarely found on other islands. The island has an attractive panorama with clean beaches and lush evergreen trees along its shores. Cow Island 


\section{Sapi Island}

Sapi island is a small island with a surface area of approximately 25 acres. A variety of coral reefs and marine life can be found in this area, which has beautiful white sand beaches. The most popular activity among foreign tourists is swimming, snorkelling, and scuba diving. The island is also equipped with basic facilities, such as a camping site, barbecue area, public toilets, and recreational areas.

\section{Sulug Island}

Sulug Island has an area of 8 hectares and is located the furthest from Kota Kinabalu as compared to other islands. Aside from the natural environment and the sea surrounding the island, the island is still underdeveloped. The coast is made up of rocks and coral reefs. Sulug Island is an ideal destination for tourists looking for a quiet and peaceful atmosphere. There are many species of fauna and marine flora on the island, as well as beautiful and rare corals.

The number of international tourists visiting Malaysia's islands has increased significantly since 1987 when Sipadan Island was declared one of the best scuba diving destinations in the world. Malaysia has since become known as a diving destination among international tourists due to its diverse and unique maritime natural treasures. It is also exotic. Malaysian waters, especially the archipelago along the Straits of Malacca, the South China Sea, and the Sulawesi Sea, are rich in marine life. Seawater that is clear and deep provides a challenge for marine enthusiasts. Currently, one of the most effective ways to control and preserve development on an island is to designate it a marine park. Many domestic and foreign tourists are attracted to the marine park because of its peaceful and enchanting atmosphere. The status of a marine park requires tourism development to be carefully and carefully planned (Norlida Hanim et al.,2017). However, according to the visitors' remarks in the park's visitor's book, there are a number of aspects that must be addressed so that the park's natural beauty can be maintained. The purpose of this article is to investigate visitors' perceptions of the Park's attractions and the level of their satisfaction with the facilities management.

\section{Research Methodology}

An evaluation approach (evaluative) was used in this study to examine the characteristics of attractions and the level of tourist facilities in TLTAR based on the perceptions of people who had visited TLTAR before and who had visited there during this study. A quantitative approach was used in the study design. In the study, Manukan Island, Mamutik Island, as well as Kota Kinabalu were investigated.

A questionnaire was used as the research instrument. The questionnaire was developed through the use of diverse literature sources, especially regarding parameter selection and question items. The initial survey conducted in the field nevertheless assisted the researchers in improving the research instruments. Additionally, observational techniques were used. Researchers interviewed residents working on the island of TLTAR and in the city of Kota Kinabalu for this study. A total of two sessions were conducted, including a morning session in Kota Kinabalu and an afternoon session on the resort island. Independent interviews were also conducted with locals in order to get a better understanding of TLTAR. In order to gather more information, researchers attended a briefing on tourism in Sabah, including TLTAR, which was presented by officials from the Sabah Ministry of Tourism, Culture and Environment. 


\section{Findings}

\section{Demographic Characteristics of Respondents}

Table 1 shows that $71.5 \%$ of the 249 people interviewed using the questionnaire were male, and 75 were female. With $68.7 \%$ and $31.3 \%$ respectively, respondents with single status were interviewed more than those with married status. In this study, the three most populous nations are Bajau (27.3\%), Indonesia (23.7\%), and other nationalities (23.3\%). The majority of respondents were under the age of 30, representing $75.5 \%$ of the total sample. More than half of the respondents have a secondary education. Government employee is the most common occupation in the district (18.9\%), followed by self-employment $(10.8 \%)$, business $(9.6 \%)$ and other occupations $(9.2 \%)$, housewives $(2,8 \%)$ and fishermen $(0,8 \%)$.

Table 1: Demographic Characteristics of Respondents $(n=249)$

\begin{tabular}{|c|c|c|c|}
\hline Demographic & Category & Frequency & Percent (\%) \\
\hline \multirow[b]{2}{*}{ Gender } & Male & 174 & 71.5 \\
\hline & Female & 75 & 28.5 \\
\hline \multirow[b]{2}{*}{ Status } & Single & 171 & 68.7 \\
\hline & Married & 78 & 31.3 \\
\hline \multirow{5}{*}{ Race } & Bajau & 68 & 27.3 \\
\hline & Suluk & 20 & 8.0 \\
\hline & Kadazan Dusun & 44 & 17.7 \\
\hline & Malay & 59 & 23.7 \\
\hline & Others & 58 & 23.3 \\
\hline \multirow{5}{*}{ Age } & 20 years and below & 70 & 28.1 \\
\hline & $21-30$ years old & 118 & 47.4 \\
\hline & $31-40$ years old & 39 & 15.7 \\
\hline & $41-50$ years old & 14 & 5.6 \\
\hline & 50 and above & 8 & 3.2 \\
\hline \multirow{4}{*}{ Education } & Primary & 19 & 7.6 \\
\hline & Secondary & 137 & 55.0 \\
\hline & Tertiary & 85 & 34.1 \\
\hline & Informal & 8 & 3.2 \\
\hline \multirow{8}{*}{ Occupation } & Public sector employees & 47 & 18.9 \\
\hline & Private sector workers & 53 & 21.3 \\
\hline & Self-employed & 27 & 10.8 \\
\hline & Doing business & 24 & 9.6 \\
\hline & Fishermen & 2 & 0.8 \\
\hline & Housewife & 7 & 2.8 \\
\hline & Students & 66 & 26.5 \\
\hline & And others & 23 & 9.2 \\
\hline
\end{tabular}

There were six characteristics of tourist attractions in the park found based on the respondents' perspective. Tourists visiting TLTAR were primarily attracted to the beach and sea $(40.2 \%)$ followed by the peaceful island environment $(27.3 \%)$ and the recreational activities, including snorkelling (12.5\%); swimming and scuba diving (12\%). Tourism attractions, along with transportation and accommodations, are among the fundamental components of the tourism 
Volume 6 Issue 24 (September 2021) PP. 87-99 DOI 10/35631/JTHEM.624008 sector (David et al., 2006). This is one of the factors that attract tourists to a particular holiday destination.

Table 2: Characteristics of Tourist Attractions in Tunku Abdul Rahman Marine Park

\begin{tabular}{|l|c|c|}
\hline Characteristics of Tourist Attractions & Frequency & Percentage (\%) \\
\hline Beach and sea scenery & 100 & 40.2 \\
\hline Isolated and peaceful & 68 & 27.3 \\
\hline Activities provided & 31 & 12.5 \\
\hline Boating & 25 & 10.0 \\
\hline Cultural activities & 19 & 7.6 \\
\hline Facilities provided & 6 & 2.4 \\
\hline Total & 249 & 100 \\
\hline
\end{tabular}

TLTAR must consider nine aspects of tourism infrastructure. Table 3 shows the ranking of the priorities according to the responses received from 249 respondents. The cleanliness of the island's environment, along with the cleanliness of the beach and sea, are the two most important aspects that need to be addressed in order to keep tourists interested in visiting TLTAR. The findings of this study are consistent with Rosniza Aznie et al. (2018); environmental hygiene is one of the practices that should be emphasized by the community in order to maintain and attract tourists.

Table 3: Aspects To Be Considered in Tunku Abdul Rahman Marine Park

\begin{tabular}{|l|c|c|c|c|c|c|}
\hline \multicolumn{1}{|c|}{ Aspects to be Considered } & $\mathbf{1}$ & $\mathbf{2}$ & $\mathbf{3}$ & $\mathbf{4}$ & Min & SD \\
\hline Cleanliness of the island environment & 2 & 4 & 32 & 211 & 3.82 & 0.482 \\
\hline The cleanliness of the beach and the sea & 2 & 3 & 34 & 210 & 3.82 & 0.473 \\
\hline Island security & 0 & 13 & 41 & 195 & 3.73 & 0.550 \\
\hline Ease of transportation to the island & 1 & 3 & 63 & 182 & 3.71 & 0.505 \\
\hline Basic facilities on the island & 3 & 7 & 80 & 159 & 3.59 & 0.610 \\
\hline Promotion about TLTAR & 2 & 9 & 81 & 157 & 3.58 & 0.605 \\
\hline Employment opportunities for residents & 3 & 13 & 106 & 127 & 3.43 & 0.651 \\
\hline Recreational activities provided & 2 & 16 & 108 & 123 & 3.41 & 0.649 \\
\hline Development of resorts on the island & 3 & 15 & 114 & 117 & 3.39 & 0.657 \\
\hline
\end{tabular}

$1=$ Not important, $2=$ Less important, $3=$ Important, $4=$ Very important

A clean beach and an environmentally friendly environment are important to visitors and TLTAR's management. In particular, the security aspect of the island, specifically the threat to certain parties and crime (3.73), is an important issue, followed by the aspect of basic facilities provided on the island with a mean score of 3.59. Nor-Ina and Ahmad Tarmizi (2016) study 
discussed on the comparative trends in crime index between Malaysian states and found that Sabah falls into the category of states with low serious crime. Patrols of the surrounding waters are conducted on a regular basis as a matter of safety for TLTAR. Aside from tourism, employment and life opportunities for locals (3.43), and recreational activities provided (3.41), other aspects that should also be considered are TLTAR's promotion to tourists with a mean score of 3.58. Among marine parks, resorts and resort development received fewer choices from respondents (with a mean score of 3.39) when determining what aspects need to be addressed for tourism development in TLTAR.

Table 4: Tourism Infrastructure - Facilities provided

\begin{tabular}{|l|c|c|c|c|c|c|c|c|}
\hline \multicolumn{1}{|c|}{ Facilities } & $\mathbf{1}$ & $\mathbf{2}$ & $\mathbf{3}$ & $\mathbf{4}$ & $\mathbf{5}$ & Min & SD & Rank \\
\hline Recreation place & 9 & 13 & 64 & 102 & 61 & 3.78 & 0.995 & 1 \\
\hline Boat & 2 & 16 & 68 & 121 & 42 & 3.74 & 0.841 & 2 \\
\hline The jetty & 9 & 13 & 71 & 104 & 52 & 3.71 & 0.974 & 3 \\
\hline Gift shop & 22 & 23 & 65 & 91 & 47 & 3.67 & 3.287 & 4 \\
\hline Signage on the island & 9 & 11 & 87 & 94 & 48 & 3.65 & 0.961 & 5 \\
\hline Rubbish bin & 18 & 24 & 63 & 92 & 52 & 3.55 & 1.139 & 6 \\
\hline Food and drink stalls & 16 & 43 & 57 & 88 & 45 & 3.41 & 1.158 & 7 \\
\hline Public toilets & 22 & 35 & 67 & 84 & 41 & 3.35 & 1.172 & 8 \\
\hline
\end{tabular}

$1=$ Very Unsatisfactory, $2=$ Unsatisfactory, $3=$ Moderate, $4=$ Satisfactory, $5=$ Very satisfying

The respondents perceive the following level of tourist facilities in TLTAR: in comparison to other facilities, the recreational facilities, boating and jetty services provided were rated as the most satisfactory by mean scores of 3.78, 3.74, and 3.71, respectively. Gift shop facilities came next with a mean score of 3.67 , followed by signage on the island (3.65) and rubbish bin facilities (3.55). The public toilet facilities are the least satisfactory of the eight facilities listed, receiving a mean score of 3.35 (Table 4 ).

\section{Discussion}

The Tunku Abdul Rahman Marine Park, located off the coast of Kota Kinabalu, is one of the closest and easiest island destinations to access compared to other island destinations in Sabah and Malaysia in general. According to a study on local perceptions of tourism development in TLTAR, it was determined that most of them are knowledgeable about the destination because of its accessibility factors. The demographic characteristics of the respondents discussed previously indicate that the nature of tourism on the island itself largely attracts male respondents $(71.5 \%)$, single adults $(68.7 \%)$ and adult youth under the age of $30(75.5 \%)$. Respondents in this group are active and enjoy challenges, especially those that involve island, 


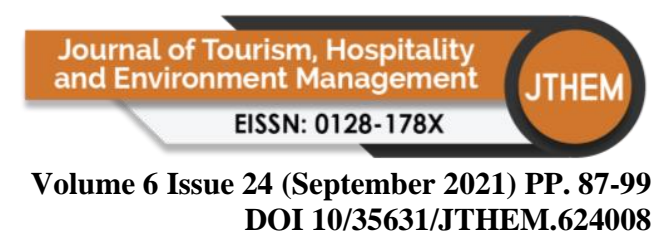

sea and beach activities. The most common reason for visiting here is a desire to learn something new, a desire to pursue a career, and an opportunity for free time with friends. Based on Zurina et al. (2016), youth tourists are motivated to travel to tourist destinations by interest as well as attraction and push factors. Generally, youths' desire to travel to a particular region is also influenced by the environment in that region. For this reason, it is imperative that the stakeholders involved prioritize efforts to preserve and maintain the natural beauty of TLTAR.

As evidenced by the observations of locals living in Kota Kinabalu and the desire of tourists visiting TLTAR, it appears that the beauty of the beach, sea, and the island environment are the main attractions for tourists and locals visiting TLTAR. TLTAR consists of five islands, each with its own unique characteristics and beauty. Gaya Island is the largest island in comparison to the others. There are two parts of the island, one of which is part of the Tunku Abdul Rahman Marine Park and the other of which is settled, particularly in the vicinity of Kota Kinabalu. According to the respondents as well as their relatives and friends who reside in Pulau Gaya, boat rides and local life do not comprise tourist attractions in TLTAR.

TLTAR is in fact a marine park, which requires special care and planning. Tourism is only concerned with aquatic life and not the local culture. Its uniqueness and beauty attract visitors to TLTAR. Tunku Abdul Rahman Marine Park is a marine sanctuary whose development is controlled and whose marine environment is protected. In addition to foreign tourists, domestic tourists, and daily visitors, the park is a popular destination for locals as well. As the result of the huge influx of tourists and visitors to TLTAR, especially during the weekends and public holidays, there is a problem of garbage disposal which threatens the beauty of TLTAR's beaches, sea, and island environment. Thus, it is not surprising that these findings indicate that the cleanliness of the coastal, sea, and island environment is a top priority in the perception of the issues that need to be addressed in TLTAR. In light of TLTAR's status as a marine park, the recreational activities that are provided and development of the resort are not factors that need to be considered, since only certain recreational activities such as snorkeling, bathing, relaxing, and picnicking are permitted. Meanwhile, jet skiing, banana boating, and other boat recreation activities are prohibited. Also prohibited is the construction of resorts, hotels, and marinas. According to Fahrul (2016), the purpose of gazette notices of marine parks is to provide special protection to aquatic flora and fauna, manage and preserve natural breeding sites and habitats of aquatic life, with emphasis on rare or endangered species. This is to prevent the extinction of aquatic life due to human activities that may damage the marine park. Thus, the reduction of activities that are likely to pollute and damage nature contributes to the cleanliness of the environment in TLTAR.

Since the TLTAR marine park is regularly visited by tourists, daily visitors, and locals, efforts are being made to improve the level of facilities on the islands. Taking into consideration the perception of the locals, it can be concluded that the place and space for beach and sea recreation, the boating and jetty facilities are good and satisfactory. However, there are a number of other facilities that also require attention, such as the provision of rubbish bins, especially in beach areas with many visitors. The full bins should be emptied immediately from time to time to prevent tourists and visitors from dumping garbage and food waste everywhere. Although food stalls are available, they can still be improved in terms of their number, cleanliness, and quality of service. The public restrooms are also available but cannot accommodate many visitors, particularly on weekends and public holidays. There is a need to Copyright (C) GLOBAL ACADEMIC EXCELLENCE (M) SDN BHD - All rights reserved 
provide several public toilets and removable changing rooms at various locations on the island. For improved service quality, a number of efforts need to be undertaken to empower the tourism sector, ranging from specific provisions for comfortable facilities, affordable and clean food services, and the planning of various and interesting activities (Muhammad Afiqsyah et al., 2016).

\section{Conclusion}

Tunku Abdul Rahman Marine Park, located off Kota Kinabalu, is closest to most other island destinations in Sabah and Malaysia in general. This study found that visitors have very good knowledge of its tourism development due to TLTAR's accessibility factors. Kota Kinabalu's natural beauty as well as the island's environment draw tourists and locals alike to TLTAR. A major advantage of TLTAR is that it consists of five islands, each with its own beauty and uniqueness. TLTAR itself is a marine park that must be well maintained and planned and known for its preserved marine treasures, which are beautiful and unique to the region. Marine parks serve a number of purposes including the protection of aquatic life and flora, the management and preservation of habitats, and the protection of rare and endangered species. It is intended to prevent the extinction of aquatic life due to human activities that may harm the marine park (Fahrul, 2016). By reducing activities that pollute and damage the environment, TLTAR maintains a clean and healthy environment. As mentioned, TLTAR is frequently visited by tourists, daily visitors, and locals, so efforts have to be continued to improve the quality of services on the islands.

\section{References}

David, W. H., Wright, D., Reynolds, N., Ellison, M. B \& Ellison, R. (2006). Passport : An Introduction to the Tourism Industry. Thomson, Canada.

Fathilah Ismail, Roseliza Mat Alipiah, Noraien Mansor \& Wan Hafiz Wan Zainal Shukri. (2020). A cross-cultural study of destination attributes: Impact on sustainability of island tourism. Journal of Sustainability Science and Management, 15(1), 1-14.

Formica, S. (2002). Measuring destination attractiveness: A proposed framework. Journal of American Academy Business, 1(2), 350-355.

Hofmann, N. (1979). A Survey of Tourism in West Malaysia and Some Economic Implications. Research Notes and Discussions Paper Institute of Southeast Asia Studies, Singapore.

Jabil Mapjabil, Yahaya Ibrahim \& Tan Wan Hin (eds.) (2014). Pelancongan Pulau di Malaysia. Batu Pahat: Penerbit UTHM.

Jung Yang, Yuting Ge, Quansheng Ge, Jianchao Xi, \&Xuenming Li. (2016). Determinants of Island Tourism Development: The Example of Dachangshan Island. Institutes of Geographic Sciences and Natural Research, CAS, 100101, Beijing, China.

Kadir Din. (1993). Dialogue with The Host: An Educational Strategy Towards Sustainable Development. In Hitchcock, M., V. T. King \& Parnwell, M (Eds.). Tourism in South East Asia. London: Routledge.

Malaysia. (1975). Pelan Pelancongan Malaysia. Perbadanan Kemajuan Pelancongan Malaysia.

Malaysia. (1980). Rancangan Malaysia Keempat. 1980 - 1985.

Malaysia. (1985). Rancangan Malaysia Kelima. 1985 - 1990.

Malaysia. (1991). Rancangan Malaysia Keenam. 1991 - 1995. 


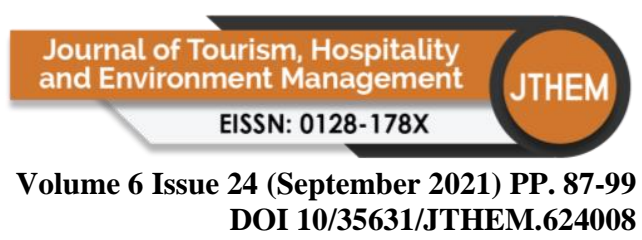

Mendoza-González, G., Martínez, M. L., Guevara, R., Pérez-Maqueo, O., Garza-Lagler, M. C. \& Howard, A. (2018). Towards a sustainable sun, sea, and sand tourism: the value of ocean view and proximity to the coast. Sustainability, 10, 1012, 1-15.

Mohd. Anuar Md. Amin. (2009). Faktor tarikan pelancongan pantai: Kajian kes di pantai Port Dickson, Negeri Sembilan. Prosiding PERKEM IV, Jilid 2, 243-254.

Muhammad Afiqsyah Mohd Ramli, Muhammad Arif Nasir, Dina Syamilah Zaid \& Hartini Adenan. (2016). Kepuasan pelanggan terhadap kualiti perhidmatan homestay di Melaka: Kajian kes di Homestay Seri Tanjung. Journal Hospitaliti dan Jaringan, Vol. 1(206), 81-90.

Muhammad Fahrul Khalid. (2016). Peruntukan Perundangan di Taman Laut Sultan Iskandar. Universiti Teknologi Malaysia.

Norazimah Mukhtar. (2015). Peranan ciri-ciri destinasi dan kepuasan pelancong kepada lawatan ulangan ke Melaka. Tesis Sarjana (Tidak diterbitkan). Fakulti Alam Bina, Universiti Teknologi Malaysia.

Nordin Sakke, Aliakbar Gulasan \& Jabil Mapjabil. (2016). Prosiding Seminar Sains Ruang dan Teknologi Maklumat Geografi. Fakulti Kemanusiaan, Seni dan Warisan Universiti Malaysia Sabah.

Nor-Ina Kanyo \& Ahmad Tarmizi Abdul Rahman. (2016). Pengalaman terhadap perlakuan jenayah dan keselamatan pekerja perusahaan rumpai laut di Semporna, Sabah: Satu penemuan. Unit Penyelidikan Etnografi dan Pembangunan, Fakulti Kemanusiaan, Seni dan Warisan Universiti Malaysia Sabah.

Norlida Hanim Mohd Salleh, Md Shafiin Shukor \& Siti Hajar Mohd Idris. (2017). Impak pembangunan pelancongan ke atas persekitaran manusia dan fizikal komuniti Pulau Tioman. Akademika 87(3), 49-62.

Rosniza Aznie Che Rose, Zainor Nizam Zainal Abidin \& Rosmiza M.Z. (2018). Kesedaran komuniti terhadap pengurusan kebersihan dalam kawasan perkampungan homestay di Daerah Temerloh. Geografia Malaysian Journal of Society and Space, 14(1), 158-174.

Pearce, D. (1987). A Geography of Tourism. London: MacDonald \& Evans.

Remali Yusoff \& Nor' Azurah Md Kamdari. (2017). Faktor tarikan pelancongan pantai: Kajian kes di Pantai Irama Bachok, Kelantan. Proceedings of International Conference on Economics 2017 (ICE 2017), 480-492.

Tajaluddin. (1994). Panggilan Pulau. Dewan Ekonomi. November 1994: 35-37.

Velan Kunjuraman, Rosazman Hussin \& Abdul Rahman Ahmad. (2015). International tourist satisfaction towards tourism activities and facilities: A case study in Mamutik Island, Kota Kinabalu, Sabah, East Malaysia. Journal of Tourism, Hospitality and Culinary Arts, 7(1), 76-92.

Vengesayi, S., Mavondo, F. T. \& Reisinger, Y. (2009). Tourism destination attractiveness: Attractions, facilities, and people as predictors. Tourism Analysis, 14, 621-636.

Wilkinson, P. F. (1989). Strategies for tourism in Island Microstates. Annals of Tourism Research, 16(2), 153-175.

Wong, P. P. (1993). Tourism vs Environment: The Case of Coastal Area. Bordrecht: Kluwer.

Zurina Ahmad Saidi, Habibah Ahmad Hamzah Jusoh\& Fatin Umaira Muhamad Azlan. (2016). Pencirian pelancong belia dalam pelancongan acara semasa Tahun Melawat Malaysia 2014. Geografia Malaysian Journal of Society and Space, 12(13), 107-119. 